\title{
Entre imagens, modernidade e religião: a iconologia protestante no Brasil
}

\section{Entre imágenes, modernidad y religión: la iconología protestante en Brasil}

\section{Pictures, modernity and religion: a Protestant iconology in Brazil \\ Priscila Vieira e Souza'}

\author{
Palavras chave: \\ Modernidade \\ Fotografia \\ Protestantismo \\ Visualidade
}

\section{Resumo:}

Esse artigo propõe examinar as relações entre modernidade, protestantismo e fotografia a partir de um percurso teórico e de um acervo imagético. O primeiro busca compreender as relações entre modernidade, visualidade e a história do protestantismo no Brasil. Tais inter-relações compõem a primeira parte do texto. A segunda parte do texto descreve o acervo imagético. As análises apresentadas enfocam duas coleções: os arquivos do Centro Audio Visual Evangélico - O CAVE; e The Grubb Collection, conjunto de álbuns pessoais do missionário britânico Keneth Grubb. O texto apresenta resultados parciais da pesquisa, tais como uma breve descrição de três tipologias classificatórias das imagens protestantes; o status privilegiado da fotografia; e dois recortes temáticos que agregam imagens dos dois acervos estudados. 
Resumen:

Este artículo propone examinar las relaciones entre modernidad, protestantismo y fotografía a partir de un recorrido teórico y de un acervo imagético. El primero busca comprenderlas relaciones entre modernidad, visualidad y la historia del protestantismo en Brasil. Estas interrelaciones componen la primera parte del texto. La segunda parte del texto se centra en el acervo imagético. Los análisis presentados describe dos colecciones: Ios archivos del CentroAudio Visual Evangélico - el CAVE; y The Grubb Collection, conjunto de álbumes personales del misiónero británico Keneth Grubb. El texto presenta resultados parciales de la investigación, tales como una breve descripción de tres tipologías clasificatorias de las imágenes protestantes; el estado privilegiado de la fotografía; y dos recortes temáticos que agregan imágenes de los dos acervos estudiados.

\section{Palabras clave:}

Modernidad

Fotografía

Protestantismo

Visualidad

\section{Keywords:}

Modernity

Photography

Protretantismo

Visuidade

\section{Abstract:}

This paper is about the relation between modernity, Protestantism, and photography. The first part of the paper explores a theoretical framework to understand these relations and to develop a visual approach to the history of Protestantism in Brazil. The second part of the paper has its focus on analyzing pictures and images from two archives: the Evangelical Audiovisual Centre (CAVE); and The Grubb Collection, a collection of personal photographs produced by Keneth Grubb, a British Missionary in Brazil. The paper then presents partial results of this research, such as a proposal of a typology to classify three different kinds of Protestant images; the privileged status of photography in these relations; and two themes that are central in the pictures and images of both archives. 


\section{Entre imagens, modernidade e religião:} a iconologia protestante no Brasil

\section{Introdução: pesquisa, contexto e metodologia}

Esse artigo propõe examinar as relações entre modernidade e protestantismo a partir de um percurso teórico e de um acervo imagético. O primeirobusca compreender as relações entre modernidade, visualidade e a história do protestantismo no Brasil. Tais inter-relações compõem a primeira parte do texto. O acervo imagético é composto por duas coleções: os arquivos do Centro Audio Visual Evangélico - O CAVE, abrigado pelo Centro de Memória Metodista da Universidade Metodista de São Paulo (UMESP), em São Bernardo do Campo, Estado de São Paulo; e The Grubb Collection, conjunto de álbuns pessoais do missionário britânico Keneth Grubb, que se encontram no Royal Anthopologycal Institute (RAI), no centro da cidade de Londres, Reino Unido. Breve descrição das análises empreendidas e alguns de seus principais resultados, entre eles a compreensão de uma iconologia protestante no Brasil, compõem a segunda parte da reflexão.

\subsection{A questão de pesquisa e seu contexto}

Antes, contudo, de adentrar as questões anunciadas, cabe demonstrar os principais elementos que compuseram a pesquisa, desenvolvida junto ao Centre for Iberian and Latin American Visual Studies CILAVS, na Universidade de Londres, durante pesquisa pós-doutoral" empreendida entre 2015 e 2016. De forma simples e direta, pode-se enunciar o problema-central da seguinte forma: considerando os víncu- los dos protestantes com processos modernizadores e a percepção iconoclasta do grupo, qual o contexto e o rastro histórico-icônico das imagens caveanas?

A formulação da questão coloca a necessidade de examinar cada parte de seu enunciado. Nesse artigo abordamos a relação ente protestantismo e modernidade e apresentamos resultados da busca pelo contexto histórico-icônico das imagens caveanas, que compõem o maior acervo de imagens protestantes encontrado no país. A expressão "percepção iconoclasta" será desconsiderada, em respeito ao espaço e a necessidade de abordar as outras questões com maior profundidade. Vale ressaltar, contudo, que a percepção iconoclasta protestante está intimamente ligada às relações históricas do grupo com a modernidade ${ }^{\text {III }}$ (BESANÇON, 1997). A questão apresentada faz referência a pesquisa anterior, de doutoramento, em que o arquivo do CAVE foi organizado e analisado. O CAVE foi uma agência de mídia que produziu programas de rádios, informativos e muitas imagens, que eram usadas para montar diafilmes e diapositivos: os filmes fixos, que uniam a técnica de projeção de imagens às de reprodução sonora. A sonoplastia desse tipo de filme era realizada de duas formas: através de aparelhos técnicos como gravadores acoplados a alto-falantes; ou, de modo mais rudimentar, a leitura no microfone do texto correspondente a cada quadro/ imagem.

Institucionalmente, o CAVE era uma organização sem fins lucrativos, com um complexo sistema administrativo ${ }^{\prime v}$, e embora não tenha sido uma experiência única na América Latina ${ }^{\vee}$, certamente destaca-se na história de produção audiovisual brasileira, especialmente por dois motivos: o financiamento estrangeiro, independente de apoio governamental; e a capilaridade alcançada. Os produtos do CAVE chegavam, através de missionários residentes ou de viagens missionárias, aos lugares mais distantes do país. 
A agência CAVE funcionou entre os anos de 1951 e 1971. Após 45 anos do fechamento do Centro Audio Visual Evangélico - CAVE, e seu quase esquecimento na memória protestante, o conjunto de documentos recolhido pelo Centro de Memória Metodista - CMM abriga 1435 imagens, 361 eslaides e 20 diafilmes completos. Pelos catálogos que compõem o acervo documental, isso é um pequeno remanescente. Essa intensa produção realizou-se com os objetivos de educação/ formação e evangelização, conforme os estatutos da organização. Durante a pesquisa realizada para doutoramento, esses arquivos foram organizados; catalogados; a partir das informações da etapa de catálogo, selecionou-se um conjunto menor para análise; tal conjunto foi digitalizado; e, finalmente, analisado.

Os resultados dessa pesquisa prévia (de doutoramento) apontaram para as relações entre os protestantes e os processos modernizadores das sociedades ocidentais e, especificamente, do Brasil. Uma das questões, então, da pesquisa seguinte (aqui parcialmente apresentada) era se tal relação se dava no âmbito do CAVE ou se seria uma característica mais ampla, presente em outras imagens produzidas por protestantes. Estabelecido um primeiro recorte histórico, buscou-se, então, identificar imagens anteriores ao CAVE para a análise comparativa. Às possíveis semelhanças entre as imagens, o rastrohistórico propriamente, propomos chamar iconologia. O termo surge, então, inicialmente, como hipótese e também passou a integrar a metodologia de pesquisa, apresentada a seguir.

\subsection{Percursos e procedimentos metodológicos}

Em termos metodológicos, o percurso teórico foi construído com base em pesquisas bibliográficas que privilegiam intersecções entre dois dos três elemen- tos estudados (modernidade, imagem, protestantismo). Mostrou-se de grande relevância obras sobre a história do protestantismo no Brasil, tanto pelo tipo de análise contextual das imagens, quanto para a compreensão das relações estabelecidas no contexto brasileiro. Sobre modernidade e religião, o tema da secularização mostrou-se incontornável. No presente texto, destaca-se a obra Uma era Secular, do pensador canadense Charles Taylor (2010). Considerada por Jose Casanova (2010) como uma abordagem que revisita o debate sobre secularização e suas diferentes nuances, fortemente presente na sociologia da religião durante o século $X X$. Contudo, o sociólogo espanhol diferencia o trabalho do autor canadense dizendo que, "na verdade, o interesse principal de Taylor não é oferecer um balanço da secularização em termos das teorias padrão de secularização, que medem as taxas de mudanças (principalmente queda) de crenças religiosas e práticas em sociedades modernas contemporâneas" (CASANOVA, 2010, p. 265) $)^{\mathrm{VI}}$. Para ele, o interesse principal de Taylor seria uma "descrição fenomenológica das 'condições' seculares de crença" (Idem).

O apoio na obra de Taylor deve-se a dois principais motivos. Primeiro, o deslocamento que ele faz, ao recolocar a questão da fé na contemporaneidade. A pergunta é realizada então, não em termos de secularização, mas das possibilidades de crer. Nessa perspectiva, a falta da fé nas sociedades atuais (em comparação com as sociedades pré-modernas) não é simplesmente uma condição de ausência de crença, mas sim uma condição histórica. O outro motivo para a escolha de Taylor é que em seu método genealógico ele busca na história as raízes de fenômenos que emergiram com força a partir do século XVII, como o humanismo e o secularismo modernos. Ao propor tal percurso, toca o ponto que aqui enfocamos: os vínculos entre protestantismo e 
modernidade, desde os movimentos religiosos que se deram no entorno da Reforma Protestante.

Os resultados das análises imagéticas, expostos na segunda parte do artigo, foram construídos com respaldo na investigação iconológica. Compreende-se iconologia como estudo histórico-antropológico centrado nas imagens e capaz de transcender os marcos disciplinares em privilégio das relações imagéticas, então analisadas transdisciplinarmente. Para tanto, a abordagem antropológica permanece como perspectiva e adotou-seprocedimentos metodológicos próprios à área da comunicaçãovlI. Isso se justifica pelo fato de que as imagens foram consideradas também como produto midiático, e em conjunto com os textos que Ihes cercam. Dessa forma, privilegiou-se elementos da análise de conteúdo, considerando o produto visual dentro do contexto cultural-histórico-imagético.

Convém observar que a análise de conteúdo realizada não se limita aos aspectos quantitativos do método. Assim, agrega às categorias analíticas (HANSEN, 1998, p. 106-108): a) questões relacionadas à técnica e estética das imagens (cores, planos, enquadramento etc.); b) a observação das relações entre imagem e texto, nos produtos em que os dois elementos estão vinculados; c) a apresentação de objetos, cenas, paisagens que em uma fase exploratória pareceram repetir; d) e um espaço descritivo-analítico em que são marcadas percepções subjetivas que, conforme Priest (PRIEST, 2009, p. 172), enriquecem a análise de conteúdo com a aproximação etnográfica. Seguimos o que a autora chama de "close readings", que considera a experiência do observador com a mídia observada, em analogia com a 'observação participante' no ambiente social. Assim, o resultado final dessa etapa, além de identificar padrões repetidos no conjunto de imagens já revela as rela- ções contextuais. Por fim, categorizamos as imagens pesquisadas, a partir também do percurso teórico realizado e efetuamos a análise comparativa.

A partir das observações acima, sobre os modos de construção da pesquisa, passamos a primeira parte anunciada: o percurso teórico.

\section{Modernidade, protestantismo e visualidade}

No Brasil, a associação entre as então novas tecnologias visuais, especialmente a fotografia e a modernidade marcou fortemente a passagem do século XIX para o século XX. Luciana Martins (2013) apresenta essa relação através de fotos e documentários produzidos nas primeiras quatro décadas do século $X X$. A autora cita, por exemplo, como a representação do indígena romantizado na pintura é sobreposta na fotografia pelo "sucesso na aculturação". Para Martins a fotografia foi conscientemente eleita por positivistas para difusão de seus ideais e projetos de sociedade: "como positivistas brasileiros sabiam bem, o poder do estado moderno dependia fortemente do poder das imagens"VIII (MARTINS, 2013, p. 1).

Também na virada dos séculos XIX-XX, o protestantismo de missão chegava ao Brasile era recebido por liberais, especialmente nos centros urbanos, como um aliado da modernização. A associação entre protestantismo, modernidade e progresso no Brasil aparece tanto na análise do pensamento social protestante de Silas Souza quanto na historiografia clássica de Antônio Gouvea Mendonça (MENDONÇA, 2008). Para Souza, o liberalismo "era parte constitutiva da mensagem evangélica" quando foi implantado na América Latina (SOUZA, 2005, p. 227-228). Esse seria um aspecto facilitador, já que parte da sociedade nos países latino-america- 
nos simpatizava com correntes políticas e econômicas liberais.

As expectativas eram, então, duplamente reforçadas. Por um lado, liberais epositivistas esperavam do protestantismo de bases norte-americanas e europeias novos ares religiosos, alternativos à hegemonia católica, e novos ideais sociais, associados ao desenvolvimento e progresso.Por outro lado, os missionários norte-americanos eram fruto da doutrina do destino manifesto, imbuídos da esperança de empreender uma tarefa messiânica-civilizatória.

O protestantismo norte americano, responsável pela implantação da religião no Brasil, desenvolveu-se com características próprias ao seu contexto. Contudo, a influência dos protestantes europeus foi uma constante. Prova disso é o avivamento wesleyano vivido na Inglaterra ter se propagado e difundido com velocidade do outro lado do Atlântico. Assim, aassociação entre protestantismo e modernidade, que emergiu no contexto brasileiro na passagem para o século XX, possui raízes históricas que remontam à Reforma Protestante. Em sua descrição da "nossa era secular", o pensador canadense Charles Taylor (2010) apresenta uma narrativa que perpassa a Idade Média, em busca de deslocamentos que culminariam nas rupturas dos reformadores. Em seguida, prossegue medievo e renascença à dentro, ressaltando traços da secularização em curso.

Em jornada genealógica, Taylor retoma movimentos religiosos que buscavam uma devoção mais intensa e interior, ainda três séculos antes da Reforma Protestante, como aparece nos escritos e práticas do Mestre Eckhart, século XIII. O autor canadense ressalta que não se tratava de um caso isolado, mas "um grande número de iniciativas nessa direção" vigorou durante o medievo, tanto entre o clero me- nor quanto entre o "crescente número de laicos mais cultos e reflexivos"(TAYLOR, 2010 , p. 93). Esses grupos teriam criado uma elite religiosa, diferenciada do povo, mas que também não era clero. Preparava-se, assim, o ambiente propício à Reforma do século XVI.

Tais grupos reforçavam uma espiritualidade centrada no indivíduo, o que se diferenciava das práticas mais coletivas e institucionais do período. Taylor mostra como o fomento dessa devoção individualizada abriu espaço e lançou as bases para o desenvolvimento do humanismo que floresceria a partir da Renascença. Esses aspectos religiosos são abordados como movimentos no pensamento e nas práticas que culminariam, no século XVIII, com o deslocamento da razão para o centro da compreensão do mundo. Em suanarrativa histórico-filosófica, Taylor enfatiza o quanto a racionalidade moderna era impensável e improvável alguns séculos antes dela emergir no ocidente.

A dinâmica de sobreposição da razão à fé na modernidade revela tensões culturais da história do Ocidente. Após um longo período em que a fé ocupou o lugar central no pensamento e nos fundamentos das sociedades, inaugurou-se um período em que a centralidade do pensamento (e do sentido) recaiu sobre o homem e a razão. Amaral exemplifica esse movimento, ressaltando que "no século XVII, Deus foi uma hipótese necessária para Descartes e Newton, mas uma hipótese. No século XVIII, podendo, a hipótese deveria ser evitada" (D'AMARAL, 2009, p. 17).

A Reforma Protestante consolida dentro da religião elementos que corresponderiam a modernidade e mesmo com as correntes anti-religiosas do moderno. Dentre tais elementos, Taylor destaca a individuação e a autonomia, diretamente ligados ao enfraquecimento institucional da religião: ao estimular a relação pessoal 
com o divino, a igreja torna-se cada vez menos necessária para o florescimento espiritual. Doutrinas como a pré-destinação calvinista também retirariam da igreja seu poder de controle dos indivíduos: cada um passava a ser dono da verdade sobre a sua salvação.

A Reforma ainda engendrou questões que possibilitariam a secularização, como o que Taylor (2010, p.103) chama de deslocamento do "centro de gravidade da vida religiosa". O poder de Deus, na concepção mais individualizada e menos ritualizada da fé, deixava de operar a partir de sacramentais ou lugares sagrados. De certa forma, isto significaria a quebra da distinção entre sagrado e profano: "para os salvos, Deus santifica em todo lugar, por isso também na nossa vida diária, nosso trabalho, nosso casamento e assim por diante" (TAYLOR, 2010, p.103). Então, se o salvo vive o sagrado em todo o tempo e em todo lugar, todos as dimensões da vida são sagradas e, por isso, devem ser ordenadas a partir de uma percepção religiosa. Contudo, diferente do que havia até então, este ordenamento não significava que todos fossem membros da igreja ou, principalmente, que todos fossem salvos - porque esta questão, a partir daquele momento, seria individual. Por isso, embora o ordenamento da totalidade da vida fosse um projeto com motivações religiosas, não se tratava de um empreendimento da religião, nos sentidos de salvação e devoção.

Seria, portanto, nesta direção que se desenvolve a distinção entre público e privado. E, neste sentido, tal distinção tratava-se de uma maneira de pensar uma sociedade ordenada, cujo ordenamento foi fabricado por vias religiosas, mas em que nem todos eram salvos, pessoas de fé. A distinção teria, assim, um duplo sentido: 1) organizar a vida religiosa em uma sociedade secular, no sentido em que essa sociedade agora abrigava salvos e não-salvos, sendo esta uma questão pessoal; 2) e, principalmente, organizar a vida não-religiosa (pública) em uma sociedade cujo ordenamento era divino, apesar de nem todos crerem ou estarem destinados a viverem como salvos.

Uma vez existindo a distinção, a possibilidade de separar a dimensão da fé da vida social, o espaço público desenvolve-se junto a outras mudanças em curso, ao próprio pensamento moderno. Afinal, configura-se como o lugar da racionalidade científica, da objetividade e da política. Quando a sociedade já não precisaria de um ordenamento que fosse a partir do religioso, ainda que posto como uma proposta secular, o espaço público se tornaria, também, lugar ausente de religião e de fé. Neste ponto, a fé já deixara de ser uma questão universal; contudo, a verdade, ou, pelo menos, o verdadeiro prosseguiria universal e necessário.

A noção de secularização foi cunhada no século $X X$ como tentativa de descrever o enfraquecimento religioso que aparecia, naquele momento, como consequência ou mesmo sintoma dos processos modernizadores. Um longo debate travou-se na sociologia e a secularização foi pensada em diversas camadas: a individual, que percebia a drástica redução do número de pessoas que creem (atualmente questionável); a camada institucional, pensada a partir da perda de relevância social das igrejas.Sem adentrar em profundida no debate, vale ressaltar que a noção de secularização marca a passagem para o moderno. De fato, parece haver consenso entre estudiosos, que no medievo, a religião abrangia o todo social e, assim, fundamentava a construção da sociedade, da cultura, das relações entre indivíduos, a formação de comunidades $^{\mathrm{IX}}$. O religioso desempenhou papel encompassador (MARIZ, 2006) por um longo período da história do ocidente. A divisão entre público e privado, então, 
está ligada ao deslocamento da religião do centro da sociedade, exercendo função de coesão social, para as dimensões da vida familiar, das opções pessoais. $O$ público tornou-se, então, o lugar de construção e definição da sociedade, com uma racionalidade específica, que se instituiu como científica, objetiva.

Os vínculos entre protestantismo e modernidade, conforme Taylor aponta, estão arraigados na história. A consolidação da divisão entre público e privado, no sentido de o religioso ser do âmbito do privado, embaça a percepção de que o que seria a modernidade iniciou-se com movimentos religiosos. Considerando o papel encompassador da religião, não havia outro lugar em que esses traços pudessem ser gerados.

\subsection{Protestantes, modernos e americanos: influências do puritanismo}

O protestantismo que chega ao Brasil atravessou primeiro o norte-atlântico. Ele advém dos Estados Unidos, carregando herança anglo-saxã, e transformou-se na América. O protestantismo norte-americano surge com a migração de grupos puritanos da Inglaterra para o novo continente. O puritanismo pode ser definido pela mescla de influências de doutrinas protestantes gestadas em diversos países da Europa. Contudo, o embasamento teológico é calvinista e, por isso, é considerado uma ramificação desse pensamento (Mendonça, 2005).

Os puritanos tinham fugido da Grã-Bretanha por causa das perseguições da rainha Maria, a partir de 1555 . Muitos foram para Genebra, onde estiveram ainda mais imersos no calvinismo. Parte deles retornou para a Inglaterra no reinado de Elizabeth. Algumas das características puritanas eram a oposição radical a festas populares, reivindicação de reformas na Igreja Anglicana - a acusavam de ser romanizada e hierarquizada ao extremo. Também eram dedicados aos estudos da Bíblia e, portanto, grandes conhecedores, de onde tiravam fundamentações para suas demandas. Defendiam uma moralidade restrita e rígida, exigindo que a Igreja da Inglaterra "adotasse disciplina severa contra clérigos e leigos cuja conduta moral não satisfizesse os padrões elevados do modelo genebrino" (MENDONÇA, 2005, p. 64).

Sua oposição ao anglicanismo e a posição republicana de parte do grupo ${ }^{x}$ gerou perseguições da Igreja inglesa e muitos puritanos foram para a então colônia americana, "a fim de construir uma nova sociedade, mais coerente com suas aspirações" (CUNHA, 2007, p. 38). De fato, eles foram muito influentes nos Estados Unidos, se viam com a missão de "estabelecer um novo Estado puritano que servisse de orientação a todos os cristãos em toda parte do mundo" (Idem). A fonte no calvinismo de Genebra embasou a compreensão de que a fé puritana deveria afetar aspectos tanto individuais com a moralidade comportamental rígida - quanto das estruturas sociais, adaptando o "dogma reformado às necessidades de uma religião pública e pessoal" (MENDONÇA, 2005, p.64).

O calvinismo puritano, observa Mendonça (2005, p.69), ainda hoje domina grande extensão da área do protestantismo, no mundo, "especificamente naquela que percorre o longo caminho Inglaterra Estados Unidos - América Latina". Destacam-se três características do puritanismo que, dentre as que permanecem presentes no protestantismo brasileiro (segundo Mendonça, 2005), contribuem com a compreensão das inter-relações com modernidade e visualidade.

O denominacionalismo é uma das marcas da história da migração puritana para as Américas. Fugindo de persegui- 
ções e guerras de religiões na Europa, eles se embrenharam na missão de construir uma sociedade que fosse religiosa e ao mesmo tempo plural. Entendendo a realidade de uma igreja do Estado como opressora, eles criaram o multi-denominacionalismo. Essa tendência facilitou a expansão do protestantismo, pois tornava a estrutura flexível e, portanto, ajustável a novas realidades políticas e sociais. Nos Estados Unidos, a valorização da liberdade eclesiástica foi essencial para a formação do modelo do país, com leis que asseguravam a existência de diversas denominações - característica levada para o Brasil.

$\mathrm{Na}$ experiência norte-americana, as instituições eclesiásticas se diferenciavam pelas formas de governo, algumas práticas e doutrinas menores. Havia, no entanto, uma unidade ao redor de um conjunto básico de valores e princípios e um espírito cooperacionista, que foi fundamental no posterior empreendimento das missões internacionais. O denominacionalismo foi criado para lidar com a tensão entre a construção de uma sociedade que ao mesmo tempo fosse fortemente religiosa e preservasse a escolha individual.

A segunda característica puritana é a ênfase na pregação, complementada pela adoção de simplismo litúrgico. Essa marca, também presente no protestantismo brasileiro, tem sua origem em uma das oposições dos puritanos à Igreja inglesa. A liturgia anglicana, que era ligada aos ritos medievais, foi simplificada ao extremo, com perda de ritualística e simbologia. A formação da então "nova" sociedade também abriga essa característica: as atenções recaem sobre o discurso. A centralidade da pregação exigiu "um elevado padrão de preparo acadêmico dos pastores" e, por outro lado, "o modelo puritano de costumes e as implicações do testemunho pessoal como exemplo da própria pregação exigiam dos pastores elevados padrões de vida moral" (MENDONÇA, 2005, p.80). O esforço de preparar esses líderes, aptos à pregação intelectualizada, gerou a demanda de escolas - Harvard, fundada em 1636, é em parte fruto desse tipo de preocupação. Havia, ainda, a preocupação de estabelecer uma cultura intelectualizada - capaz, portanto, de assimilar os sermões ministrados nas igrejas.

Por fim, o asceticismo é outro forte elemento puritano que chegou, séculos depois, ao Brasil. Junto ao simplismo litúrgico e retirada de simbologias dos hábitos anglicanos, os ideais ascéticos do grupo influenciam diretamente a visualidade.

Essa proposta puritana ascética de relação com o mundo é ilustrada no livro O Peregrino, escrito por John Bunyan, em 1678. O texto é rico de linguagem visual, sendo que as edições ilustradas foram amplamente aceitas. O texto narra a história de um homem que tem que escolher entre dois caminhos: um áspero e estreito, em direção à Cidade de Deus e outro largo e prazeroso, que leva à Cidade da Destruição. Sua opção pelo primeiro o leva a uma jornada de dificuldades, tentações e sofrimentos. Mendonça $(2005$, p.68) analisa como a alegoria "contém elementos desviantes da teologia calvinista" e cita como principal a possibilidade do indivíduo escolher, mesmo à beira da morte, seguir para o outro caminho - aspectos contrários à forte ênfase calvinista na "graça irresistível e a perseverança dos santos" (Idem).

A obra de Bunyan influenciou fortemente a gravura "O Caminho Largo e o Estreito X'". Segundo estudo de Leonildo Campos, o quadro teve presença expressiva nas casas e ambientes protestantes no Brasil, especialmente durante a primeira metade do século XX (CAMPOS, 2014). Ele teria sido desenhado na Alemanha, em 1862. Posteriormente, foi publicado e amplamente difundido na Inglaterra. 
O quadro dos dois caminhos é um antecedente pictórico de fotografias protestantese traz elementos que aparecem nas imagens da câmara escura, produzidas durante o século XX no Brasil, como adiante apresentamos. Três desses elementos são marcantes. O primeiro, uma alegoria que lança mão do realismo, em detrimento do simbolismo: prédios, pessoas e até mesmo os caminhos, tudo é desenhado com uma perspectiva realista. O segundo elemento é o uso da imagem para a representação de realidades espirituais. Por fim, o cerceamento da polissemia imagética pelo texto: uma das versões do quadro possui grande quantidade de texto, tanto indicando o que as figuras são ("Teatro", "Clube" e outros) quanto apresentando referências bíblicas para as figuras.

Neste ponto inicia-se o trabalho iconológico. Antes, contudo, de nele adentrar mais detalhadamente, ressaltamos o quanto essa história influencia a chegada e implantação do protestantismo no Brasil. Mesmo com os séculos que se passaram entre o berço (ainda) colonial dos ideais puritanos que se instalaram na América do Norte e o início do protestantismo no Brasil, a pretensão de pluralidade foi mantida. Assim, chegaram em solo brasileiro, a partir do final do século XIX, missionários de diferentes tradições denominacionais: congregacionais, presbiterianos, batistas - para citar alguns. Uma marca presente na decisão dessas pessoas em enfrentar os desafios de uma vida em locais de menor estrutura do que seu próprio país era a compreensão de que o catolicismo não seria suficientemente cristão e estaria demasiado deturpado, mais próximo ao paganismo (CUNHA, 2007, p.39). Esses empreendimentos missionários também foram estimulados pelos avivamentos do século XIX, que levaram renovação e engajamento religioso a todo os Estados Unidos, fortalecendo os grupos evangelicais.

Pode-se afirmar, então, que dois fatores levaram à associação entre protestantismo e modernidade no Brasil: aspectos históricos mais distantes, que podem ser identificados nos movimentos pré, durante e pós Reforma; e a origem norte-americana dos missionários. Vale lembrar que no final do século XIX, os EUA emergiam como um potencial econômico, considerando a América Latina como sua óbvia área de influência. Os aspectos históricos foram na maior parte das vezes usados superficialmente como argumento para deslegitimar a cultura nacional. Faziam-se comparações de riqueza das nações do Norte-Atlântico, destacando que as protestantes seriam mais ricas e 'desenvolvidas' que as católicas. As comparações entre países procuravam "provar a superioridade civilizatória do protestantismo, que se espalhava tanto no progresso material como moral dos países anglo-saxões" (MENDONÇA, 2008, p.132). Doutrinas e práticas católicas seriam responsáveis pelo "atraso material e moral dos países latinos" (Idem). À parte a argumentação rasa (que coloca na conta apenas da religião os múltiplos processos e fatos que se inscrevem na história das sociedades), a relação histórica entre protestantismo e modernidade é densa, intrínseca. Envolve processos de secularização e deslocamentos que engendraram mudanças profundas nas formas de pensar e de experimentar o mundo.

Importante ainda ressaltar, as ambiguidades dessa relação entre protestantismo e modernidade. Ao mesmo tempo que aspectos do estilo de vida "moderno" são condenados e integram o "largo caminho" que conduz à punição eterna, outros desenvolvimentos modernos são assimilados. A herança moderna histórica, da Reforma Protestante tensiona, assim, com a ascese puritana. 


\section{Imagens e fotografias protestantes no Brasil}

O que propomos aqui chamar de iconologia protestante no Brasil é o conjunto de imagens produzidas por pessoas e/ou organizações que se auto definem como protestantes.Como mencionado acima, o termo iconologia agregou à pesquisa tanto uma hipótese quanto um método. Conforme os resultados dos acervos já analisados em perspectiva comparada, a hipótese confirma-se, como demonstra-se a seguir, as imagens protestantes de diferentes autorias/momentos/ lugares/ denominações apresentam semelhanças. Tais similaridades permitem caracterizar tanto a relação (e os usos) dos protestantes com a imagem quanto o que seria uma imagem(s) protestante(s) - ou seja, o que esse conjunto apresenta de peculiar, e que se repete.

Com tais questões identificadas, a primeira etapa da pesquisa identificou três diferentes tipos de imagens produzidas e/ ou utilizadas por protestantes na primeira metade do século XX (sem considerar o arquivo CAVE). O agrupamento é realizado por finalidade e técnica de produção. São eles:

A) Educação cristã infantil: as imagens aparecem como ilustração de materiais didáticos e exploram elementos lúdicos (Bellotti, 2007). O desenho, frequentemente colorido, é a principal técnica de produção.

B) Imagens mnêmicas e/ou inspirativas: figuras diversas, que buscam retratar histórias bíblicas (com função mnêmica) ou realidades espirituais (inspirativas, sem deixar de apelar à memória), que compunham quadros, nas casas dos fiéis. Identificamos (Leonildo, 2014) que os protestantes brasileiros tinham por hábito pendurar quadros com mensagens religiosas em suas casas. A prática, que também aparece entre protestantes norte-americanos(MORGAN, 1999), foi comum aos fiéis da primeira metade do século XX. O "Quadro dos dois caminhos" é o exemplo mais consistente encontrado. Estima-se que duas representações repousavam em tais imagens: de realidade espirituais abstratas; e histórias bíblicas. Como a pesquisa aborda tema pouco estudado, não foi possível encontrar outros registros em bibliografia. Nesse tipo de imagem, acredita-se que a maior parte seja composta por gravuras. Mas o enfoque técnico aqui é a reprodução.

C) Fotografias do Brasil (em geral, produzidas por missionários estrangeiros): o início do século foi marcado pelas viagens para "os novos mundos", com registros fotográficos e textuais que alimentavam um culto ao exótico (MARTINS, 2001). Missionários europeus viajavam com o olhar atento às peculiaridades religiosas, mas também contribuíam com os registros de outras dimensões da vida e das sociedades além mar.Inicialmente, localizou-se na bibliografia quatro fontes de fotografias do Brasil de autoria de missionários protestantes: texto de autoria de Luciana Martins (2013), que analisa parte do arquivo fotográfico do missionário Kenneth Grubb; a publicação The Republic of Brazil - a survey of the religious situation, de Erasmo Braga com ilustrações de Grubb (New York: World Dominion Press, 1932.); o "acervo Grubb", que contém fotografias ainda não publicadas, localizado no Royal Anthropologicallnstitute, em Londres; a publicação Braziland The brazilians, dos missionários James Fletcher e D. P. Kidder (London: SampsonLow, Marston, Searle, And Rivington, 1879).

O primeiro resultado, então, da pesquisa iconológica foi a busca por essas referências e a divisão do material encontrado em três diferentes tipologias. 
O arquivo CAVE foi desconsiderado na listagem, já que a proposta parte dele e buscaconjuntos icônicos anteriores. Em perspectiva comparativa, encontra-se similaridades já nas descrições gerais da primeira etapa da pesquisa. O CAVE herdou dois dos três tipos de imagens anteriores à organização: produção de material didático para educação cristã e fotografias. Nas fotografias, identifica-se, ainda, um tipo de representação que remete aos quadros protestantes: a ilustração de realidades espirituais.

A etapa seguinte foi a seleção do enfoque da pesquisa, o recorte de quais imagens comporiam o corpus documental específico. Como a questão central considera as relações do grupo estudado com a modernidade, ao mesmo tempo que a pesquisa bibliográfica e teórica apontou para as relações entre processos modernizadores e técnicas de produção e reprodução de imagens, a fotografia destacou-se como locus privilegiado de análise. Além disso, conforme já assinalamos, as fotografias do CAVE dialogam com as três tipologias compostas na primeira etapa.

\subsection{Privilégios e primazias da técnica fotográfica}

$\mathrm{Na}$ análise do arquivo CAVE resultou a percepção de que a fotografia possui um status diferenciado no conjunto de imagens protestantes. O CAVE utilizou diversas técnicas de produção de imagens, como desenhos, pinturas, colagens, reproduções de revistas dentre outras. Os filmes fixos compostos por tais imagens também possuíam finalidades e públicos alvo diversificados: evangelização direta (não crentes); mensagem religiosa indireta (não crentes); educação e formação cristã para crianças e adultos (fiéis).

Em temos de público alvo, a técnica da câmara escura foi utilizada para atingir tanto protestantes quanto não protestantes. Contudo, um recorte específico do público foi constatado: apenas produtos direcionados a adultos utilizaram da fotografia, o que sugere que o grupo produtor de tais imagens excluísse o lúdico da "natureza" ou das possibilidades fotográficas. Ainda em relação ao público alvo, a fotografia aparece como a imagem preferencial nos produtos elaborados para atrair a atenção das pessoas. Isso ocorria - aqui já discorrendo sobre as finalidades do uso da técnica - através da apresentação de coisas (plantas, animais, paisagens, construções) com a intenção de causar no público efeito de apreciação do belo e de encantamento.

Por fim, também em relação a finalidade, a fotografia era escolhida para narrar "realidades": além da já citada representação de conceitos da espiritualidade evangélica, através da analogia, ela também aparece para compor narrativas de histórias de pessoas, especialmente histórias de conversão religiosa (Figura 1).

\subsection{Técnica e natureza: descrição e encantamento}

A definição do conjunto fotográfico estabeleceu-se como o primeiro recorte ao grupo de imagens protestantes localizadas na primeira etapa da pesquisa. Em seguida, um segundo fechamento fez-se necessário, por questões de viabilidade do trabalho. Estabeleceu-se, assim, que a comparação seria realizada entre o conjunto de fotografias digitalizadas do arquivo CAVE e a Coleção Grubb. Trata-se de arquivo com imagens do Brasil sobre o qual um único trabalho existia, o da pesquisadora Luciana Martins, supervisora da investigação que aqui se apresenta. Além disso, considerou-se também a oportunidade de focalizar tal arquivo, já que a pesquisa se desenvolveu no local em que ele está guardado. 


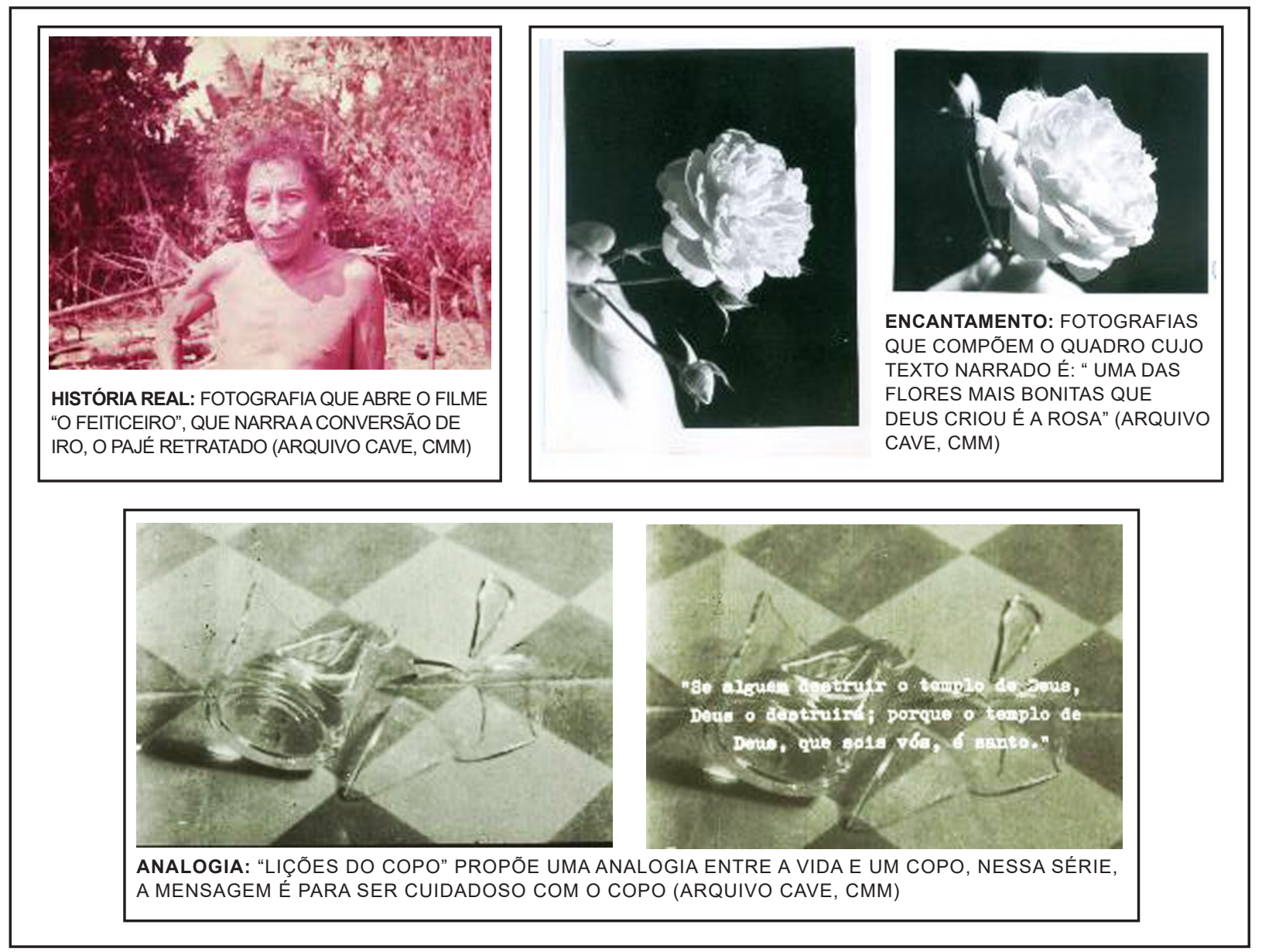

Figura 1: Usos da fotografia na iconologia protestante Fonte: elaboração própria; fotos: Arquivo CAVE, CMM

A análise comparativa permitiu identificar as similaridades entre os dois arquivos. Dentre diversos elementos e características semelhantes, demonstram-se dois: A) a preocupação em fotografar natureza; B) e o olhar atento a objetos técnicos.

\section{A) Natureza, ciência, fé}

A presença de imagens da natureza, é marcante em ambas as coleções.Nos textos no entorno das imagens, aparecem descrições e abordagens que sobrepõem a descrição científica a uma revelação espiritual. Há uma busca por reconciliar natureza e criação, ciência e Deus, retomando e insistindo no potencial do primeiro conduzir ao segundo.
Ao comparar o produto caveano "Árvores e flores do Brasil" com fotos de Grubb dispersas pelos álbuns (organizados pelo autor e/ou por sua esposa prioritariamente por localidade), percebe-se que a semelhança é inegável. As fotos do início da década de 1930 (GrubbCollection) poderiam ser usadas para compor a narrativa construída pelo CAVE entre o fim de 1963 e o início de 1964.

A observação cuidadosa das imagens de flores revela um padrão fotográfico: a divisão de planos; o jogo de focalização do primeiro plano enquanto desfoca o segundo; a centralidade na foto do elemento eleito como principal pelo olhar do fotógrafo (Figura 2). 
Outra semelhança captada é um jogo entre geral e particular; o todo e o detalhe. $\mathrm{Na}$ coleção Grubb, o jogo todo-detalhe é meramente ilustrativo, embora aponte para o uso descritivo da fotografia: influência, supomos, da descrição científica. No produto do CAVE, em que há abundância textual para complementar a análise, tal jogo integra um racio- cínio indutivo em que afirmações sobre particularidades, cujas fontes podem ser tanto da experiência da observação quanto de estamentos científicos, conduzem necessariamente à conclusão de que a criação divina é maravilhosa. A autoapresentação do diafilme cria a expectativa dessas conclusões, que se repetem ao longo da narração (Figura 3).

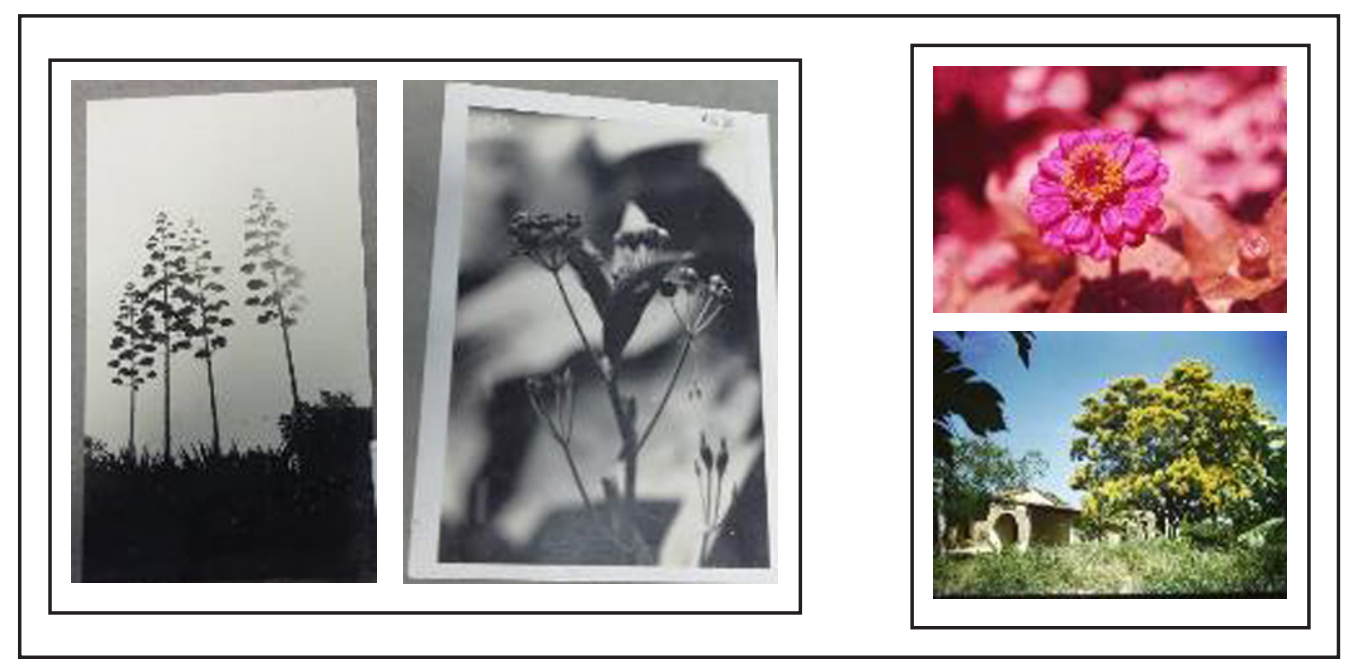

Figura 2: Exemplos de fotografias/ natureza

Fonte: elaboração própria: as duas imagens à esquerda são da GrubbCollection e as imagens à direita são do Arquivo CAVE

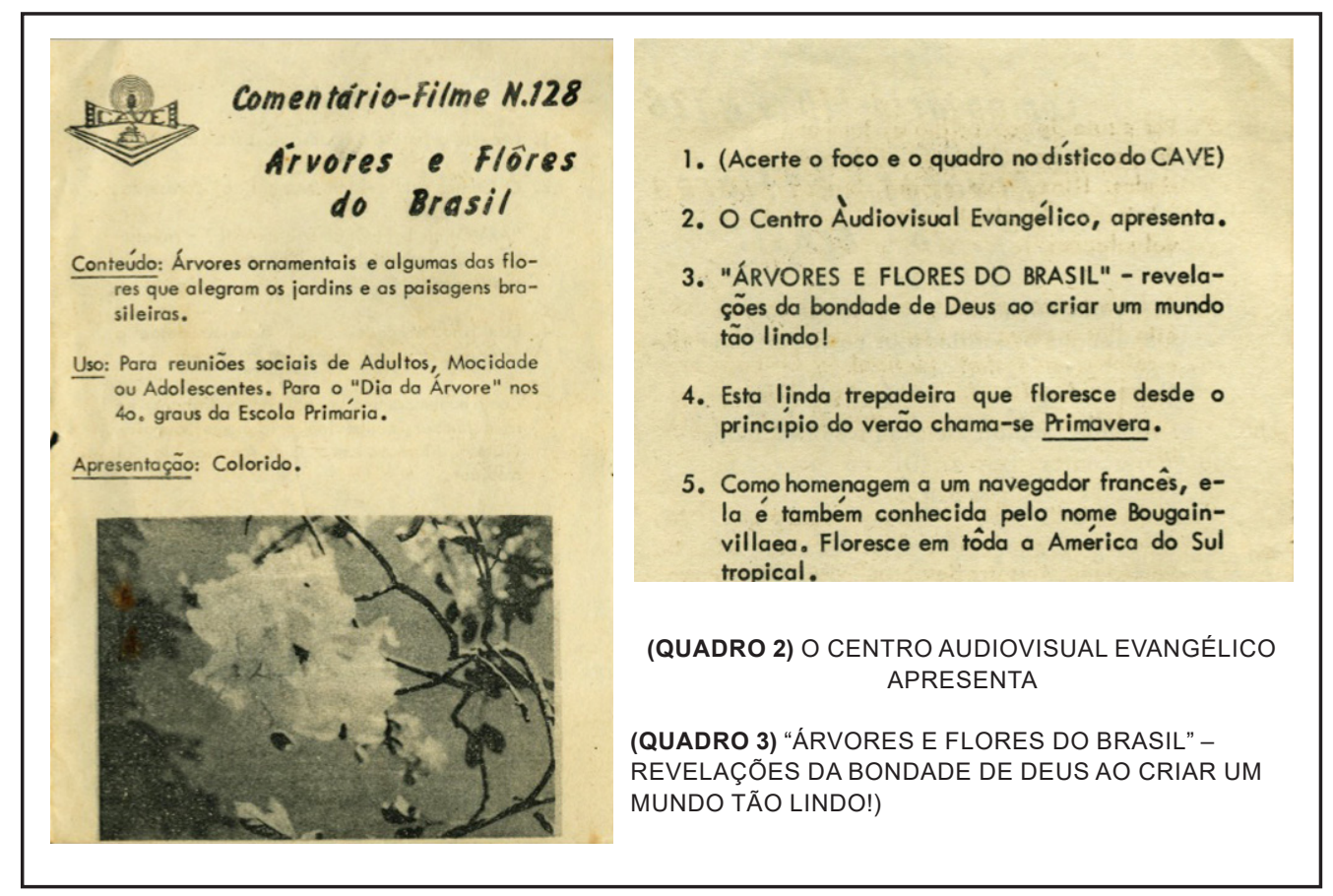

Figura 3: Diafilme "Árvores e flores do Brasil" p.1 e p.2 Fonte: elaboração própria a partir do Arquivo CAVE 
Embora o produto seja apresentado de forma integralmente religiosa, o texto que segue mescla informações científicas sobre as plantas, como nomes em latim, procedência, habitat. Também procura informar os diferentes nomes populares que a planta recebe em diferen- tes lugares, inclusive nos Estados Unidos. Reproduzimos abaixo o penúltimo quadro do diafilme (o quadro anterior é sobre o Ipê branco), que exemplifica essa mistura de informações científicas e culturais sobre a planta, conduzindo a conclusões sobre a criação.

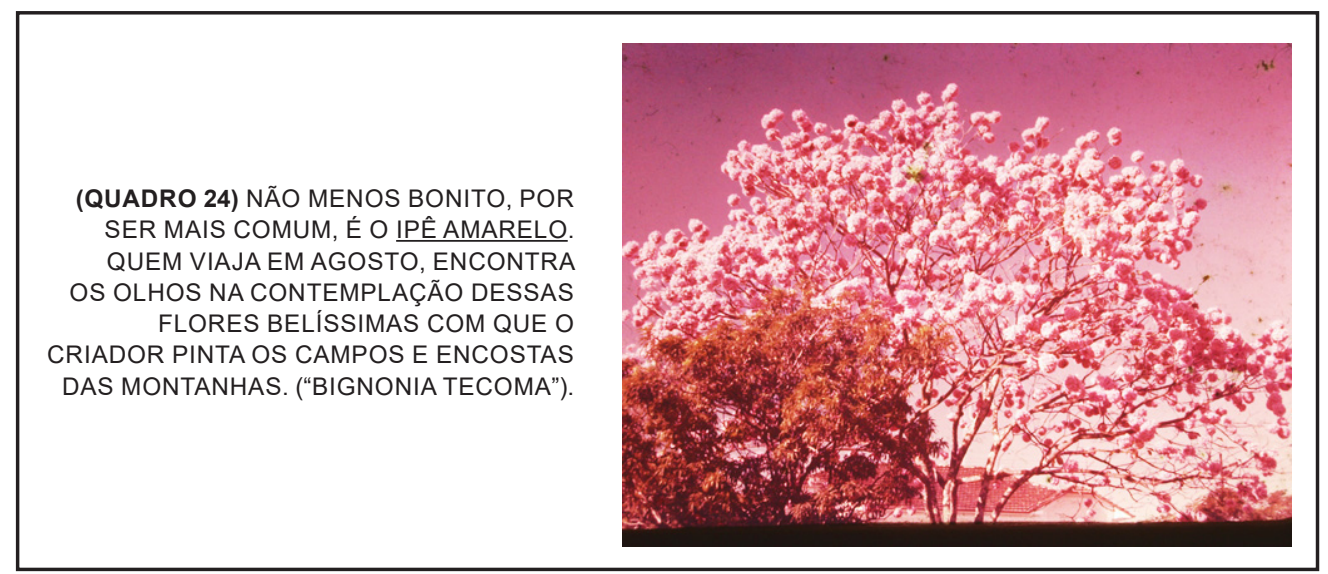

Figura 4: Quadro com respectivo texto "Árvores e Flores do Brasil Fonte: elaboração própria a partir do Arquivo CAVE

A dimensão espiritual da natureza, sua capacidade de revelação do divino, era evidentemente a intenção do diafilme. Isso fica ainda mais claro em documento de comunicação interna encontrado nos arquivos, que insere uma descrição sobre o produto em processo de produção. A mensagem está, em sua maior parte, em inglês. Destacamos alguns trechos, em tradução livre da autora:

Além de apenas lindas flores (...) o comentário faria uma forte combinação com o fato de que a beleza delas é uma criação de Deus. (...) O cuidado de Deus mesmo nos mínimos detalhes é demonstrado pela vista mais de perto das mesmas flores, uma vez que a obra de Deus é maravilhosa até a menor parte; em contraste, a obra do homem pode ter uma aparência à distância que não resiste a um exame de perto. (CAVE. Comunicação Interna. 18/05/64.)

Esse trecho ressignifica os planos fechados. Se eles são, como sugerimos, influenciados pelo método descritivo da ciência moderna, então são características dessa mesma ciência que conduzem à apreciação do divino. Uma reminiscência, talvez, do primeiro moderno, de Blaise Pascal e Francis Bacon. Uma evidência da relação protestante com a modernidade e, ao mesmo tempo, da leitura que o grupo procurava fazer da ciência. Nesse trecho acima apresentado, a capacidade descritiva da fotografia ganha um sentido espiritual. No entanto, isso não está na fotografia em si; a espiritualidade emana da natureza. Embora isso não seja tão óbvio nos álbuns de Grubb, no texto que analisa as imagens do missionário, Martins (2013, 
p.73) destaca em uma das publicações dele exatamente a "voz espiritual" dada à natureza: "In Parables from South America (1932), published by the Lutterworth Press, Grubb delineates a distinctively moral geography, in which he gives spiritual voice to the 'mute and inarticulate scenes of nature'".

\section{B) Técnica rudimentar $\mathbf{X}$ técnica moderna}

Técnica e tecnologia são diretamente apresentadas nas imagens e textos de ambos os acervos. A presença da tecnologia aparece como positiva, até mesmo necessária. Comumente, as técnicas 'rudimentares' locais são opostas às tecnologias 'modernas', incluindo a ciência. $\mathrm{Na}$ Coleção Grubb, isso aparece através de sutilezas nas imagens e principalmente nas legendas. A técnica aparece no lugar do rudimentar, da curiosidade descritiva, o peculiar, o exótico; já em relação à tecnologia/ ciência, é possível captar positivações e atribuição de valor superior.

Por exemplo, o arquivo de Grubbpossui retratos diversos de pontes. Chama a atenção nas legendas a diferença entre "A rustic bridge" (uma ponte rústica) e "The Bridge" (A Ponte). Sutilezas: sabe-se que a língua inglesa reserva o uso do artigo determinado ("The") para quando a intenção é marcar a unicidade do substantivo que segue. Tal artigo não costuma ser usado nem mesmo antecedendo nomes próprios de pessoas. $\mathrm{O}$ mesmo ocorre com a marcação da primeira letra maiúscula no substantivo: em português, dizemos, um substantivo próprio, algo distinto dos demais objetos que podem ser referenciados com a mesma palavra. Na outra legenda, em contraposição, observamos o artigo indeterminado e todas as letras minúsculas, além da adjetivação "rústica". Esse texto marcado pela indeterminação sugere, também, a existência de diversos outros objetos com características similares, dentre os quais, o texto refere-se a "um", uma unidade dentre vários do mesmo.

A "ponte rústica" é o texto escoIhido como legenda de uma imagem em que se vê Keneth e sua esposa em pés em uma trilha estreita cortada em meio a árvores altas e plantas baixas - uma paisagem de floresta. As cabeças estão voltadas para o fotógrafo (atrás), enquanto a posição dos corpos sugere que caminhavam (e que prosseguiriam) para adiante - para "dentro" da fotografia, no caminho que divide a imagem ao meio. Em frente ao casal, ve-se degraus "rústicos", indistintamente de madeira ou mesmo de barro. A legenda, nesse caso, revela que se trata de uma ponte - o que a imagem, por si só, não diz.

A imagem que recebe a legenda "A Ponte", determinada e própria, exibe a construção da Ponte Hercilio Luz (apenas mais tarde assim nomeada), na cidade de Florianópolis, capital do Estado de Santa Catarina. A foto integra um conjunto de imagens sob o nome da cidade. A ponte que liga a parte insular da cidade a sua continuidade no continente é, desde o anúncio de sua construção (que ocorreu durante a década de 1920), considerada um marco de modernização do país.

O aspecto curioso da técnica "rudimentar" aparece em uma série de imagens, na coleção Grubb, que retratam nativos com instrumentos comuns ao meio rural brasileiro do início do século $X X$ : um engenho de açúcar, que é antecipado por uma imagem cuja legenda indica uma "Prensa de açúcar caseira Terena" (Terena homemade sugar press). A indicação da etnia que, ao menos acreditava o missionário, desenvolveu a técnica revela sua preocupação com a etnologia de que fala Martins (2013). Outra imagem que integra a mesma página é uma "Prensa de mandioca" (Mandioca press). Nessa, 
os traços indígenas dos dois homens que ladeiam o aparato e a presença de uma criança nua no colo de um deles evidenciam que se trata de um instrumento utilizado pelos nativos. Além disso, há também a indicação da localização no início da página: "Bananal, Indian Mission" (Bananal, Missão indígena). Sabemos, portanto, que as imagens foram realizadas na missão que abrigava nativos, especialmente da etnia Terena.

No CAVE, o diafilme "O Feiticeiro" oferece diversos exemplos da captura de técnicas indígenas e de tecnologia e ciência introduzidas pelos missionários (a um grupo Yanomami) (Quadro 4). Nos produtos do CAVE captamos uma oposi- ção entre "civilização" e "miséria", em um discurso sobre a necessidade de 'amparo' aos indígenas em que compreende-se a "vida na floresta" como algo que solicita intervenção. O diafilme "O Bom Samaritano" está, provavelmente, entre as produções mais antigas da agência. Notamos isso por ser preto e branco, pela qualidade das imagens e as técnicas utilizadas. O filme, após narrar a estória bíblica do Bom Samaritano, questiona "De quem devemos ser próximos", o que, no contexto, significa: "A quem devemos ajudar (ou amparar)?”. E então há uma série de imagens e sugestões (pobres, presidiários, órfãos, pessoas com problemas de mobilidade e outros); entre elas, estão os índios:

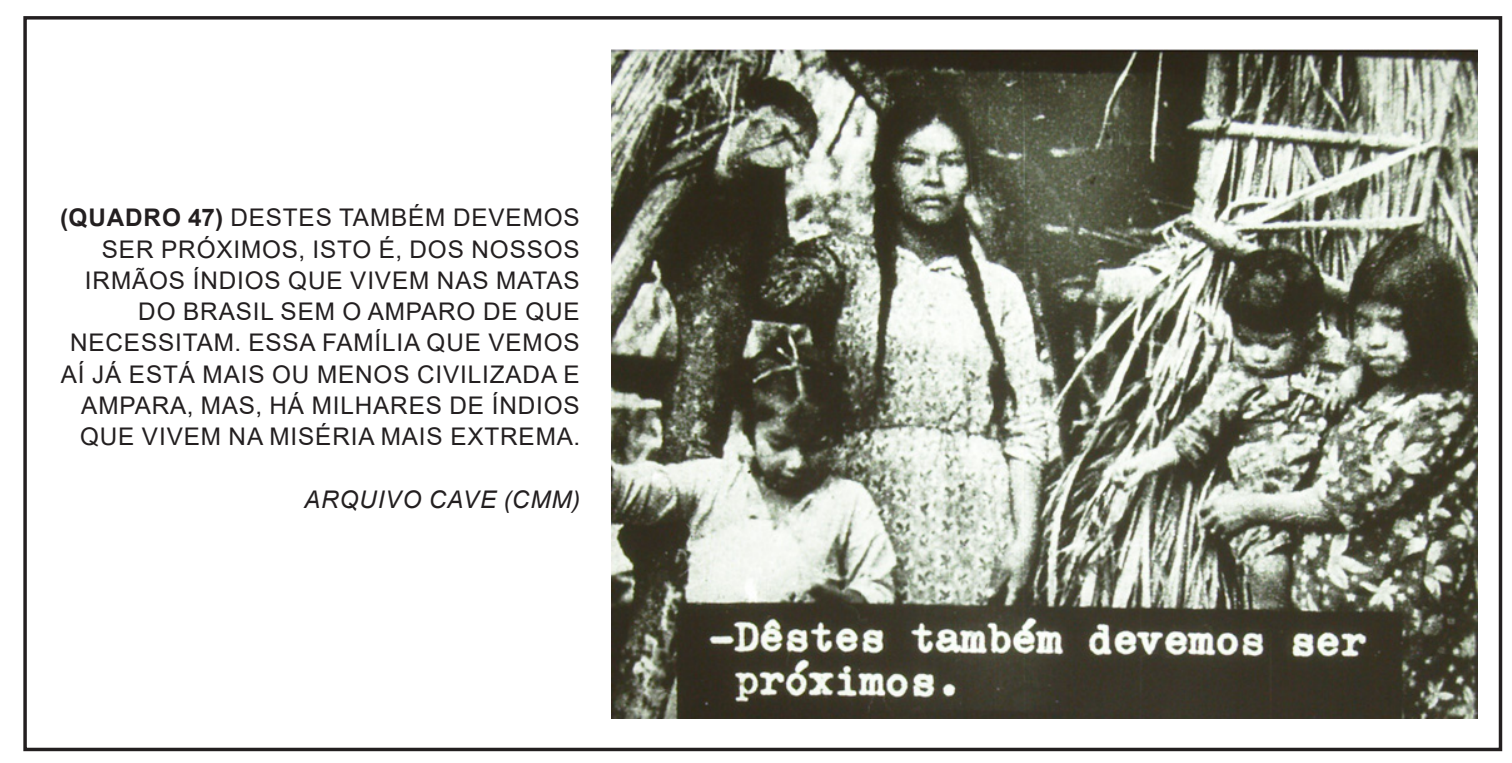

Figura 5: Quadro do diapositivo "O Bom Samaritano"

Fonte: elaboração própria a partir do Arquivo CAVE

Nos álbuns de Grubb não há referência semelhante em textos das legendas. No entanto, junto às fotos de indígenas e suas técnicas, há diversos registros de 'intervenções': cultos "do lado de fora da maloca", como diz o texto de uma das legendas; fotos de pré- dios de agências missionárias de apoio aos índios; diversas fotos de nativos com roupas ocidentais. Imagens que revelam, no mínimo, o interesse em registrar os processos 'civilizatórios' (para usar uma palavra presente no produto caveano) ou modernizadores. 


\section{Conclusões}

Anunciamos de início que o presente texto aborda duas questões: um percurso teórico e um conjunto de imagens, que estão intimamente ligados. Em relação ao 'rastro histórico-icônico das imagens caveanas', o primeiro resultado foiaclassificação das imagens encontradasem três tipologias: educação cristã infantil; imagens mnêmicas e/ou inspirativas; fotografias do Brasil. A perspectiva comparada conduziu a um segundo resultado: a identificação de um status privilegiado da fotografia em relação a outras técnicas de produção de imagens.

Trazendo a fotografia para o foco da análise, constata-se duas características do uso protestante das técnicas da câmera escura. Primeiramente, um recorte de público que exclui as crianças, direcionando os produtos originados da fotografia especificamente para adultos.E, em relação aos temas e as finalidades 'merecedores' da técnica, aparecem as narrativas de 'histórias reais' e produtos com o intuito de apreender a atenção do público e/ou transmitir informações descritivas.

A análise comparativa dos dois acervos, Arquivo CAVE e Coleção Grubb, permitiu identificar dois temas comuns: o primeiro expressa-se pela tríade natureza-ciência-fé; e o segundo pela oposição técnica rudimentar - técnica moderna. Esses dois conjuntos fotográficos, reunidos pelas suas características iconológicas, (cor)respondem à questão e percurso teóricos. $\mathrm{O}$ acervo protestante comprova que, de fato, a herança histórica de atrelamento do protestantismo à modernidade emerge para a superfície das imagens criadas pelo grupo. Especificamente na fotografia, a composição protestantismo, modernidade e imagem aparece com clareza.

No primeiro conjunto temático, natureza-ciência-fé, observa-se a proposta de conciliar ciência e religião através de ressignificara descrição científica que, então, assumiria a função de conduzir ao divino. A ciência objetiva, descritiva, que surge na modernidade é tranquilamente assimilada e adaptada à mensagem evangélica dos protestantes. Ela é colocada à serviço da compreensão da grandeza divina, como transparece no documento de produção citado.

No segundo conjunto, a oposição entre técnica rudimentar e técnica moderna privilegia noções como progresso e desenvolvimento - típicas dos processos modernizadores do início do século $X X$. $\mathrm{Na}$ análise das imagens, percebe-se a positivação da técnica moderna e mesmo "a carência" dela, como se sua ausência fosse sinônimo de sofrimento.

A análise das imagens comprova, portanto, a hipótese da relação entre modernidade, técnicas visuais e protestantismo. O empreendimento messiânico-civilizatório toma forma nessas imagens que, em seu conjunto, opõem o "rústico" com o propriamente moderno. Dentre as caracterizações do moderno, traçadas no percurso teórico, destaca-sea dessacralização de lugares específicos que, de certa forma, foi um processo de sacralização da vida comum. Esse aspecto que Taylor aponta como consequência da Reforma Protestante revela-se na expectativa dos protestantes do século $X X$ de que uma imagem descritiva (fotografia) de elementos da natureza fosse capaz de conduzir a Deus. Da mesma forma pode-se compreender a tentativa de lançar o olhar divinizado sobre o discurso científico.

As características do puritanismo apresentadas, a ênfase na pregação e a ascese, também são observadas, ainda que sutilmente, nas imagens. A herança da hipervalorização do texto ajuda a explicar a necessidade de cercear as imagens com legendas (GrubbCollection) e/ou 
descrições que chegam a ser redundantes com a imagem (CAVE). Em relação à ênfase ascética, os enfoques nas histórias de transformações/ conversões é uma reminiscência desse aspecto. A ascese também pode ser relacionada com a necessidade de restringir o uso de imagens para encantamento ao objetivo evangelizador. Nesse caso, ao mesmo tempo que indica a existência de um ideal ascético, revela também seu afrouxamento.

Outras mudanças podem ser notadas, em relação a imagens mais antigas, como o "Quadro dos dois caminhos". Nessa figura, a rejeição "ao mundo" é completa e Campos (2014, p.354) sugere que ela também seja fruto da desconfiança com a industrialização, no contexto inglês. Já nas fotografias do século $X X$, os protestantes estão novamente entusiasmados com os processos modernos, sobretudo no Brasil. É nesse momento, portanto, que os vínculos históricos dos protestantes com a modernidade emergem. Portanto, a imagem mais antiga ilustra como estreito o caminho que conduz a salvação. Ainda assim, para os protestantes do início do século XX, ele era amplo o suficiente para construir-se também através da ressignificação da ciência e da técnica moderna.

\section{Bibliografia}

BESANÇON, A. A Imagem proibida uma historia intelectual da iconoclastia. Rio de Janeiro: Bertrand Brasil, 1997.

CAMPOS, L. S. Os "Dois Caminhos": Observações sobre uma gravura protestante. HORIZONTE, v. 12, n. 34, p. 339-381, 28 jun. 2014.
CASANOVA, J. A secular age: dawn or twilight? In: WARNER, M.; VANANTWERPEN, J.; CALHOUN, C. J. (Eds.). . Varieties of Secularism in a Secular Age. [s.l.] Harvard University Press, 2010. p. 265-281.

CUNHA, M. DO N. A explosão gospel: um olhar das ciências humanas sobre o cenário evangélico no Brasil. Rio de Janeiro: Mauad Editora Ltda, 2007.

D'AMARAL, M. T. As ideias no lugar: Tecnologia, mística e alteridade na cultura contemporânea. Rio de Janeiro: Editora E-papers, 2009.

MARIZ, C. L. Mundo moderno, ciência e secularização. In: BRIGIDA, E. (Ed.). Fazer Ciência, Pensar Cultura: Estudos Sobre a Ciência e a Religião. Rio de Janeiro: Centro de Ciências da Saúde, 2006. p. 97-128.

MARTINS, L. Photography and Documentary Film in the Making of Modern Brazil. Manchester: Manchester University Press, 2013.

MARTINS, L. DE L. O Rio de Janeiro dos viajantes: o olhar britânico (1800-1850). Rio de Janeiro: Zahar, 2001.

MENDONÇA, A. G. O protestantismo no Brasil e suas encruzilhadas. Revista USP, v. 0, n. 67, p. 48-67, 1 nov. 2005.

MENDONÇA, A. G. O celeste porvir: a inserção do protestantismo no Brasil. São Paulo: EdUSP, 2008.

MORGAN, D. Protestants and Pictures: Religion, Visual Culture, and the Age of American Mass Production. New York; Oxford: Oxford University Press, 1999.

PRIEST, S. H. Doing Media Research: An Introduction. London: SAGE, 2009.

SOUZA, S. L. DE. Pensamento social e político no protestantismo brasileiro. São Paulo: Editoria Mackenzie, 2005.

TAYLOR, C. Uma era secular. São Leopoldo: UNISINOS, 2010.

\section{- FONTES PRIMÁRIAS}

\section{- Imagens:}

Arquivo CAVE, Centro de Memória Metodista, Universidade Metodista de São Paulo 
Grubb Collection, Royal Anthropologycal Institute

\section{- Documentos:}

- CAVE. Árvores e Flores do Brasil. Comentário de diafilme. 25 Quadros.

- CAVE. O Bom Samaritano. Comentário de diafilme. 68 Quadros.

- CAVE. Comunicação Interna. 18 abril 1964.

- CAVE. O Feiticeiro. Comentário de diafilme. 74 Quadros

\author{
Recebido em 08/08/2017 \\ Aprovado em 12/09/2017
}

I Priscila Vieira e Souza. Doutora em Comunicação e Cultura pela Universidade Federal do Rio de Janeiro / UFRJ. Bolsista CNPq (Pós-Doutorado no PPGCOM-UFRJ). Professora da Faculdade Metropolitana de Maringá (PR) / Unifamma. Contato: priscilavieira@ufrj.br

II Bolsista Capes (Proc No. 0595/2015-02). Pesquisa Pos-doutoral no exterior.

III O historiador francês Alain Besançon (1997) propõe "uma história intelectual da iconoclastia" no ocidente. Ele identifica a modernidade como um dos grandes ciclos iconoclastas e analisa como reformadores, como Calvino, contribuíram com a iconoclastia moderna.

IV A administração se dava através de uma Assembleia formada por representantes de organizações eclesiásticas e paraeclesiásticas (missionárias), que se reunia anualmente ou bianualmente e elegia a diretoria da organização. O CAVE era dividido em departamentos, comissões e conselhos, cujas funções eram definidas em Estatuto.

V Há registros de um centro audio visual no México e outro no Peru, mas é provável que outros países tenham iniciado projetos semelhantes. O CAVE era financiado pelo National Council of Churches in Christof USA (NCCCUSA), através de dois de seus departamentos: a RAVEMCCO (Radio, Audio Visual Education and Mass Communication Commission Overseas), que tinha por objetivo criar centros pelo mundo; e o Comitê de Cooperação na América Latina da Divisão de Missões Estrangeiras, que, como o nome diz, trabalhava para criar projetos nos países latino-americanos. Informações retiradas de: BELLOTTI, Karina Kosicki. "Delas é o reino dos céus": mídia evangélica infantil na cultura pós-moderna do Brasil (1950 a 2000). Tese (Doutorado em História) - Curso de História, Universidade de Campinas, 2007. P.55-56.

VI Tradução livre da autora. No original: "Indeed, Taylor's primary interest is not to offer a sociological account of secularity in terms of standard theories of secularization, which measure the changing (mostly falling) rates of religious beliefs and practices in modern contemporary societies".

VII Aproveita-se aqui de experiências investigativas anteriores, especialmente da pesquisa de doutoramento, já citada. Algumas adaptações, como o acréscimo do elemento comparativo, serão realizadas.

VIII Tradução livre da autora. No original: "And as Brazilian positivists knew well, the power of the modern state relied heavily on the power of images".

IX Tal afirmação baseia-se em anterior revisão do debate de secularização, presente na tese de doutoramento da autora, especificamente no primeiro capítulo: VIERA-SOUZA, 2014, p.37-57. Apesar de ser fruto da reflexão de um conjunto de autores, pode-se destacar a socióloga Cecília Mariz (2006); e os estudos de Amaral (2009).

X O curto período republicano e ditatorial inglês, sob o governo de Oliver Cromwell, "foi essencialmente uma revolução puritana" (MENDONÇA, 2005, p.67). O então rei Carlos I foi deposto e morto. Dez anos depois, defensores da família real tomaram novamente o poder.

XI Também conhecido como "O Caminho da Salvação e o Caminho da Perdição" ou simplesmente "Quadro dos dois caminhos". No texto de CAMPOS (2014), há uma reprodução do quadro. O texto pode ser lido online ou baixado em PDF no seguinte endereço: <http:// periodicos.pucminas.br/index.php/horizonte/article/view/ P.2175-5841.2014v12n34p339/6690>. 